\title{
The Arab Revolution in 2011-2012 and Its Impact on Women in the Middle East and North Africa
}

\author{
Ashna Shareff ${ }^{1, ~ *, ~ K o ~ B o n g-J u n ~}{ }^{2}$ \\ Department of International Politics and Foreign Defence, Chungnam National University, Daejeon, South Korea
}

Email address:

ashna.shareff.as@gmail.com(A. Shareff),bjko@cnu.ac.kr (Ko Bong-Jun)

${ }^{*}$ Corresponding author

\section{To cite this article:}

Ashna Shareff, Ko Bong-Jun. The Arab Revolution in 2011-2012 and Its Impact on Women in the Middle East and North Africa. International Journal of Education, Culture and Society. Vol. 5, No. 1, 2020, pp. 1-9. doi: 10.11648/j.ijecs.20200501.11

Received: October 9, 2019; Accepted: January 27; Published: February 10, 2020

\begin{abstract}
This study examines the impact of the Arab revolutions on women in the Middle East and North Africa in 2011. It highlights the aftermath of the revolutions in the context of the rise of Islamist movements and their influence on the state and women. The study analyzes the role of women during the Arab uprisings and how their voices were subsequently undermined throughout the region by new institutions and governments replacing the old totalitarian regimes. This research uses a qualitative literature review with a theoretical framework based on democracy and human rights in the Arab World and political Islam with regards women. Therefore, it's focused on the period during and after the Arab uprisings and on women's status. The study mainly criticizes the negative impact political Islam had on women in public and the new patterns of the government. It inspects what we mean by democracy, why democracy is important, what kind of democracy suits Middle East and North of Africa (MENA), and the direct relation between democracy, human rights, and women's representation in particular.
\end{abstract}

Keywords: Political Islam, Democracy, Human Rights, Arab Revolution and Women

\section{Introduction}

The Arab Revolution also known as Arab Spring or Arab Uprising as widely used in the world of media symbolizes the emergence of opposed societies in the Arab world against the old regimes. The transformation started in Tunisia with the self-immolation of Tarek al-Tayeb Mohamed Bouazizi on December 17, 2010. This marked a turning point in the history of the region. Even years after the revolution, it is still uncertain whether the uprising potentially could lead to the promotion of democracy, especially in areas where women are concerned. Although with the new elections that took place very recently in Tunisia, there seems to be rays of hope igniting for the Tunisian population.

Women took to the street side by side with men during the revolutions, but soon after the rise of Islamic groups in Egypt; related Islamic groups started forming in other countries like Tunisia, Yemen, and now Syria. Women became more and more oppressed not only in public, but also in the new constitutions. Women felt were left out by the new states and their voices were silenced. Therefore, this study is going to explain how the Arab Spring has changed to an autumn for women both in public and in their representations in the new governments. It will highlight how women are being repressed and consequently how the concept of "democracy" is distorted.

Hence, in this study I will argue that although the so called 'Arab Spring' was started by women alongside men; however due to the rise of political Islam and new biased governments in particular have pushed women aside rather than including them in public and the new administrations throughout the Arab World.

\section{Theoretical Explanatory Framework}

\subsection{Political Islam}

Although, the emergence of Islamism goes back to the encounter between Islamic and the European world in the $19^{\text {th }}$ century; in reality it can be argued that the originality goes back to the times before Ash'ariyyah theology, which is a school of Sunni Islam. It evolved slowly and took over 
Islamic thoughts and as a result hindering its development.

Islamism or sometimes referred to as political Islam is known to be an ideology derived from Islam. However, the two are different units. Islam is best known as a religion while Islamism is more of an ideology. Islam suggests a set of guidelines and principles that are open to different interpretations and explain positions in relation to society and government. Political Islam on the other hand, uses a specific values and Islamic beliefs as a base and the foundation for its political organization. Therefore, Islamism can be seen as a form of institutional ideology that usually acts as a response to a challenge by a more solid state [23].

\subsection{Democracy and Human Rights}

Democracy, which is derived from the Greek word Demos (people) is defined as "government in which the supreme power is vested in the people. In some forms, democracy can be exercised directly by the people; in large societies, it's by the people through their elected agents;" according to President Abraham Lincoln's memorable phrase, democracy is "government of the people, by the people, and for the people" [21].

There is a direct relation between democracy, freedom, and human rights. Democracy is the institutionalization of freedom, and is often defined as a set of ideas and principles about the latter. However, it also stresses a set of practices and procedures that have been modeled in a long history [16]. Democratic societies are held to provide the ultimate protection of individuals' freedom. As stated in the United Nations' Universal Declaration of Human Rights: "Recognition of the inherent dignity and of the equal and inalienable rights of all members of the human family is the foundation of the freedom, justice, and peace in the world [21]".

\subsection{Democracy in the Arab World}

The process of democratization emerged in MENA only after the notion of democratization started functioning in Latin America and Southern Europe, followed by South Korea and Taiwan. However, due to the peculiarity of the area, MENA has always been an exceptional case in terms of democracy.

The process of democratization has always been slow or invisible in the Arab World prior to the Arab Revolution in 2011. For example, elections have rarely taken place in Algeria, while authoritarian regimes or militias have been the norm in Somalia. Iraq witnessed a number of partitions and war. Middle East and the North Africa have not been favorable to the notion of democracy. However, MENA countries share socioeconomic and political elements with other developing states such as the Philippines and Brazil, and civil wars are not unique to the region and do not necessarily preclude the development of democracy; notably, many Arab states like Lebanon, Morocco, Egypt, Jordan have achieved some degree of democracy.

The fundamental problem inhibiting democracy in MENA is that the political structure and the role of civil society remain weak.

Nevertheless, an important stumbling block to the proposition that free trade leads to democracy is presented by MENA. Historically, Egypt, Syria, Iraq and Tunisia all underwent significant economic liberalization from the 1980s onwards, with no concurrent advance in democracy. Free trade in the Arab states has merely expanded the social and economic dominance of elite (governing) oligarchies rather than the interests or indeed economic welfare of ordinary citizens. Political power in the Arab states remained unshared, leaving democracy, pluralism, and human rights under the shadow of the elite groups. Although in Egypt, Tunisia, and Jordan the civil society played a larger role than it did in Iraq and Syria, the majority of Arab regimes were afraid or unwilling to allow any sort of assertive civil society role. Hence, both economic liberalization and the growth in the private sector in the Arab states were not able to bring about democratization to the state; indeed, it could be argued that the most autocratic regimes - the absolute monarchies of the Gulf Cooperation Council (GCC) - have the greatest economic liberalization [19].

Nevertheless, there are different explanations on the nature and the environments suited for democracy to function. The Culturalists, who think that a particular culture or religion could hinder the process of democratization, emphasize the nature of the Islam, which they find remarkably different from all other religions.

While many scholars emphasize the side effects of Islam in hindering the process of democratization, Hisham Sharabi and Saad Inrahim stress on the role of culture in holding back democracy. Notably, Hisham Sharabi in his neo-patriarchy model emphasizes Islam and patriarchy and their relation with politics. He states, "The traditional patterns of gender relations and the typical forms of the exercise of power and authority within the family have produced patriarchal patterns of political authority in the Arab World [23]". Additionally, he states that the traditional patriarchy of the political system happens to be in the hands of bourgeois Muslim fundamentalists who represent a form of government oppressive towards women in the Arab World.

The argument that only Islamist groups appear to be undemocratic or that Islam alone is a barrier against the process of democracy is debatable. Attempts to discredit Islamists by subterfuge in Algeria by evoking the "Islamist versus democratic" split was unsuccessful in promoting democracy. As some scholars argue, democracy has much to do with the nature of political parties rather than the ideologies they adopt.

The problems Arab Middle Eastern countries have been facing in the face of democracy are many, but fundamentally power is highly concentrated among dominant elites. Almost all the ruling classes are ruled by the state and therefore there is no room for any other sorts of power and control beyond the state and powerful classes. In many Arab states in the Middle East, the private sector has become a complement of the ruling oligarchy (i.e. the state), and both private interests 
and ordinary citizens have almost no share in contributing to any form of civil society able to function alongside (and not within) the state/official machinery.

Most of the Arab states comprise traditional kingdoms fuelled by oil. These types of system make the process of democracy quite difficult as they gain their power from coercion and reward rather than legitimacy. Their development is based on oil and gas revenues, number of state employees (who become de facto stakeholders in the prevailing antidemocratic system) and domestic security. Most Arab states, as mentioned in the earlier in this chapter are recognized by their sociopolitical structure known as neopatriarchy, whereby family clans and religious groups have the authority over the social bases and organization. Similarly, compulsion, control, and paternalism are the main characteristics of structure of the state; while customs and rituals play a rather more important role than creativity and innovation [19].

Dalal al-Bizri (2011), states that democracy is vital to liberate women's political potential. Democracy involves people taking part in decisions over the form of the government and society in order to ensure satisfying ambitions and interests of the citizens. Al-Bizri argues that democracy should strengthen women since they are half of the populations [1]

Academic studies on the sources of democratization in the Middle East argue that the best model for the emergence of democracy in the Middle East is for it to come from below. They emphasize the role and importance of policy makers, donors, democracy aid supporters, and journalists in the area as indications for democratization. They believe that civil society can play a major role in the Middle East. In other words, civil society organizations, regardless of their type, agenda, or influence, all are the base for democracy because "An active associational life is a precursor of democracy" (Carothers and Ottaway, 2005: 90.) Civil society in this term is understood as "a zone of voluntary associative life beyond family and clan ties and separate from market [9]. "

\subsection{Women and Revolutions}

Revolutions generally emerge from inequalities, whether social, economic, or political. It's a reaction to lack and a request for equality that has been previously denied to them. Revolutions in general result in either an absolute change in the state or modification on an existing system. The primary factors behind revolutions go back to the inequality of wealth, state tyranny towards the citizens, fear of law, abuse of individuals, failure of middle class to maintain balance, and discriminatory actions. Revolutions have been seminal events in modern world history, notably the French Revolution in the 1790s and the American Revolution in 1776. These revolutions have transformed state organizations, the makeup of the classes, and leading ideologies. Revolutions give birth to nations whose power and autonomy noticeably suppressed their own prerevolutionary pasts and exposed other countries in similar circumstances [20].
Rachel Saloom states that revolutions and nationalism are gendered actions. According to Saloom, women's participation in revolutionary movements is essential for the success of the movement. However, although women's participation in revolutions and movements is important, they are often disadvantaged by the results of the movements. He gives an example in the context of Palestinian nationalism, which is evidenced in a "nation first, women after" frame of mind. He also argues that this concept was an obvious characteristic of the Iranian Revolution [18].

\section{The Arab Revolution and Its Impact on Women}

The Arab revolution which has began in late 2010, is a magnificent social outrage against the authoritarian regimes in the Arab world. In less than a year, street protestors were able to overthrow regimes that had been in power for decades.

Waves of the protest and revolution began on December 17, 2010, with the self-immolation of a frustrated young Tunisian vendor. The trigger behind self-immolation was mainly humiliation at the hands of the state. Subsequent protests in Tunisia spread to other Arab states throughout MENA.

On January 14, 2011, the Tunisian President Bin Ali fled the country and escaped to Saudi Arabia. The events in Tunisia were soon followed by Egypt. On January 25, 2011, the Egyptians revolted against Mubarak regime in Tahrir Square. Substantial money was given and economic reforms were made and promised to appease public anger in Saudi Arabia, Morocco, Jordan, Kuwait, and the GCC. The protests of the Libyans especially in the Eastern part of the country escalated into a full scale civil war. Humanitarian catastrophe expedition in Benghazi prompted an anglo-French intervention reinforced by the US which overpassed the militants given by the UN Security Council. This ultimately led to the overthrow of Gaddafi. Syria on the other hand, witnessed political upheavals like Egypt and Tunisia [14].

Demonstrations also took place in Bahrain where Shi'a majorities were protesting against Sunni minorities, in addition to Saudi Arabia, Yemen, and Syria. Nevertheless, the demonstrations in the Gulf were soon suppressed by the state [11]. Despite the progress the rest of the Arab states have made after the revolutions, Syria however, remains to this day in a continuous civil war.

The factors behind the revolutions in the Arab World differ, from social in inequality to instable economic conditions, political injustice, rejection of dictatorships and Arab ruling elites' corruption, in the context of rising prices.

\section{Nature of the Arab Revolution and Women}

There are a number of angles to look at and ask questions about the nature of the Arab states after the revolutions. For 
instance, has the Arab revolution achieved its goal in bringing a positive change to the Middle East? And what has it changed in the status and condition of women? This chapter will try to answer those questions.

The UN Convention on the Elimination of All Forms of Discrimination against Women (CEDAW), which is the most inclusive women's rights treaty, was written in 1979 and enforced in 1981. The treaty was ratified by 187 nation states, including all Arab states except for Somalia and Sudan. However, each Arab state has approved the treaty with considerable conditions, which undermine women's rights and the purposes of the treaty [8].

Women rights organizations across the Middle East have had many serious meetings and attempts to implement the CEDAW fully after the uprisings. For this purpose, in May 2011, feminists across the region met in Rabat, Morocco to review women's status after the Arab uprising in the region. Their aim was to make sure that the new constitutions ensure equality between men and women, politically legitimize women's role, and protect their rights [25].

The fact that the Arab women were present at the start of the uprisings in MENA indicates their strong dedication and desire for new democratic governance in the area. In fact, women were the key actors of the Egyptian uprising in 2011. One good example of female presence during the uprising is Asmaa Mahfuz, a young Egyptian activist. On January 18, 2011, Asmaa posted a video on YouTube articulating the Tunisian success against the dictatorship and calling for Egyptian liberation as well. Asmaa in her video to the Egyptian people claimed that she would not set herself alight, but instead she would go to Tahrir Square and claim her rights. Asmaa wanted liberation for the Egyptian citizens and to fight against police brutality and humiliating treatment, aside from any political affiliations. Although she faced much criticism, and numerous attempts and threats to stop her, at last she posted a video quoting the Quranic verse: "God does not change the condition of a people until they change that which is in themselves," and claiming "if you have honor, dignity, and courage, join me in Liberation [Tahrir] Square" [17]. The video had a tremendous impact on the Egyptian people, and soon thousands of other women and men joined her in the protest which later became a movement and subsequently a revolution. Soon political parties and groups joined the protest. It was in January 23 when the Muslim Brotherhood (MB) joined Asmaa's liberation movement in Egypt.

The movements which were initiated by young people and women had taken a visible lead during the uprising. The media was increasingly taking notice of the role of women in the protests. The mass consisted largely of non-religious people and secularists in Tunisia and Egypt, which implied one conclusion for the Middle East: a new era of opposition had emerged and women in particular were important actors of the opposition. New demands were claimed based on the values of freedom, justice, equality, rejection of corruption and dictatorship and initiating rule of law [17].

The Arab uprising clearly wasn't the work of any Islamist groups in the Middle East. As Tariq Ramadan notes, neither in Egypt, Tunisia, Jordan, Libya, or Syria were Islamist groups present during the start of the uprisings. In fact, the mass movements started and led the uprisings without agreement or leadership from the Islamist groups. However, soon after the revolutions and the withdrawal of the regimes, Islamism as a new trend slowly began to emerge. The MB for example started reorganizing and mobilizing its movement, and soon in Egypt, they were able to form a government under Mursi through elections. They were elected by the majority of deprived peasants. Moreover, the MB has made no prior political progress since they reached maturity during the 1930s and 1940s in Egypt, Syria, Lebanon, Algeria, Morocco and Tunisia [17].

In Tunisia, the Islamist group Al-Nahda joined the revolutions several weeks after they began. Similarly in Egypt, the MB joined the uprising weeks from the start of the revolution. The same was true for all other Arab states which witnessed upheavals, like Jordan, Syria and Yemen [14, 17]. The Islamist groups in particular changed the nature of the Arab Spring for women.

Tariq Ramadan, in his book The Arab Awakening: Islam and the New Middle East (2012) describe the mass movements that have altered the Arab states as "unfinished revolutions." "In those movements," he states, "women and men of all religions and social backgrounds took to the streets, without violence and without attacking the west to demand an end to dictatorship, to economic corruption, and to people's denied respect [17]. “

However, what happened after months from the start of the uprising changed the goals and the nature of the uprising. In both Egypt and Tunisia, the young members of Islamist organizations joined the movements mostly without the agreements of older members of the groups or advice of the hierarchal leadership. Notably, soon the Islamists who joined the mass movements took a different direction from that of ordinary citizens. The young members of the Islamist groups refused to be patient and adopted strict attitudes towards the civil society and even differed from their own organizational cultures. Through social media, they were able to mobilize themselves and create social and political relations. There was a rising risk and fear of replaying what happened in Iran in 1979 when the Islamists took to the streets with the mass movements and ended up taking control fully over the civil society and government [14].

Nevertheless, as mentioned previously, even the clerics in the Iranian Revolution pandered to women when it was useful for them before betraying them in the postrevolutionary period, while in the Arab revolutions women were subordinated by the Islamists before revolutions came to fruition.

In a program about women held by the Wilson Center's Middle Eastern program in 2012, women from all walks of life were brought together to discuss women's status under the rise of the Islamic regimes after the uprisings in the Arab World. Women in the meeting discussed their situations in the current states. In one instance, Egyptian women claimed 
that their rights have been largely overlooked. For example, after the Mubarak regime, there has been no quota system in the parliament. As a result, women's role in representing themselves and influencing decision making in the government has failed to be noticed. In one of the meetings, the women highlighted harassment on the streets that Egyptian women face continuously. Hala Esfandiari, the director of Wilson Middle East program, stated in the meeting that women are the real losers of the Arab Spring, claiming that there is little difference between Iranian women after the 1979 Revolution and the Arab women after the uprisings. The constitution seems to be one of the major problems facing women in the Arab World. Notably, it is insufficient for women's rights to be protected only by a quota system in parliament or other ways, but it is essential for Arab women to be part of the constitution drafting. As Dalia Ziada, an Egyptian activist, pointed out, the struggles women face in the post-revolutionary Egypt are similar to the periods before the revolution. In fact, she argues that the post-revolutionary struggles are merely a continuation of the pre-revolutionary ones. Ziada claims that the patriarchal nature of the Egyptian society has always marginalized women. She argues that including women in both participatory and leadership capacities is crucial to change the current status of women, and this is the only way to the process of true democratization [25].

During the transitional period in the Arab states, which was supposed to lead to constitutional drafting and democratic elections, the presence of the Islamist groups were quite visible. In fact, by late 2012 Islamist groups were fully participating in the governments of Tunisia and Egypt, and Tariq Ramadan wrote in the same year that they were "becoming a determining factor in the domestic political debate in North Africa and the Middle East" [17]. However, the MB has been successfully expelled from power and outlawed by the current Egyptian regime, representing the decapitation of Islamism throughout MENA.

To draw attention to the impact the Arab spring has made on Arab women, it's critical to look at the Arab states in general to see how women have been marginalized. Even though some of the Arab revolutions in 2011 ended up making no significant social, political changes for women in Bahrain, Oman, Algeria, Morocco, Saudi Arabia, and Syria; however it's important to show the role women have played in standing against the authoritarian regimes during the uprisings and the influence of the upheavals on women in those states.

\subsection{Arab Revolution in Tunisia}

Women were not only present in the revolution in Tunisia, but like Egypt were the initiators of the revolution. According to Souha Miladi, a teacher and trade union member in Tunisia, after Mohammed Bouzizi's self-immolation, a woman started shouting in front of municipality and asking men to join her to stand against the brutality of the government. Straight afterwards, men and women responded to the call and protests broke in the streets [10].
After the downfall of Bin Ali's regime in 2011, Tunisian women seemed to be heading on the path of achieving a degree of liberty in the new government. There were expectations that this time Tunisian women would enjoy freedom, however despite the revolutionary law that was passed by the Transitional Government in January 2011 which stated that it was compulsory that both men and women be listed as candidates to draft the new constitution, men comprised $94 \%$ of the electoral lists. Nevertheless, Tunisian women are still struggling due to Islamic state religion in Tunisia which undermines the legal significance of women's full participation in public and political life and protection of their rights [25].

After a new election held in 2011 , the two main political parties (the moderate Islamist Al-Nahda party and the secularists) won the majority of seats in the Parliament. The Salafists were the majority rule in the state and ever since the revolution; this has depressingly influenced women and their role in both public and state level. Women's organizations have widely demanded that the state lift reservations on CEDAW. Although the state approved the demand in August 2011, it was not yet officially registered with the UN. Tunisian women were concerned that even though the President has addressed women's rights, he might not actually be able to stand up against his own conservative party and Salafists in the Parliament. Women's equal rights were put into question and the majority of Tunisian women were asked constantly to veil and to be separated in public with men. Economically, the state's obligation towards women seemed to be weakened [4].

Many of the Tunisian trade unions that women make up the majority were playing a magnificent role in supporting the revolution from the very beginning. One of the most well known trade unions is Tunisian Labor Federation (Union Generale Tunisienne du Travail, UGTT)

Despite public harassment, Tunisian women faced major problem when in August 2012, the constitution assembly proposed an article that depicted women as rather complement with the men in the family and an associate to the men in the progress of the country. That's to say women were officially considered as not equal to men. Additionally, in November 2012, Tunisian assembly removed an article that stated the country as committed to ensure gender equality. The majority of those women who held high positions in the state were part of the Islamist groups. In June 2013, an interim government came to power after election. Ennahda Islamist party which was banned before the revolution won the majority votes. Women won 49 seats, and 42 seats of the women who won were affiliated to Ennahda party. This left women with no hope for any political change in the state since those women were working to serve the Islamist party rather than women's cause [12].

Nonetheless, Ennahda was not the only obstacle to democracy in the state. Many of the groups, which were banned before the revolution, began to re-appear after the uprising promoting extreme Islamism such as the Salafis. The Salafis wanted Shari'a as the basis of constitution in the 
state. Together despite Ennahda's aim to control the Salafists, both Ennahda and Salafist were opposed to secularist groups in Tunisia. After the evolution, wearing full face veils began to increase and harassment was increasing in public. The Salafis were divided mainly into two groups, those who used violence to influence the state and the society, and those who used passive methods to spread their ideology [4].

Economically, state's obligation towards women seems to be weakened and there was a lack of employment opportunities for women. Unemployment remains largely unaddressed in Tunisia despite little improvements in the economy. For example, in a poll conducted by International Republican Institute in May 2011, to highlight public opinion on unemployment and economic crisis, $66 \%$ of the respondents claimed that the Tunisian economy was bad [12]. In fact, unemployment rates to this day remain a concerning issue in Tunisia.

One of the main factors behind the economic crisis in Tunisia goes back to state's insecurity and weak domestic and foreign investment. The investment has been paralyzed ever since the revolution and most probably it will not grow in the near future due to constant political unsteadiness. Although women's economic opportunities are increasing in Tunisia compared to other Arab states; the public harassment makes it difficult for women to improve their local economic conditions [7].

Tunisian economy in the pre-revolution period was highly centralized in the hand of the previous government and ruling elite which heavily depended on domestic sector. With the little chances that women had to fit in the government and inequality in the country, employment and job opportunities were in constant decline for women. Even though one of the main factors behind the Tunisian revolution was economic inequality, Tunisia is still suffering from economic disadvantages. After the revolutions in 2011, unemployment rate were surprisingly high especially for women [3]. The revolution resembled a hope for democracy but the reality is complex. There is still a long way to go for more freedom and equality for women in Tunisia and the Arab world.

\subsection{Arab Revolution in Egypt}

Women's contribution to the Arab Spring in 2011 is not new to the Egyptian women. Women's movements have always played important role during the revolutions in Egypt. They played an important role during the British occupations in 1920 and advocated for their rights at the time. However, similar to the circumstances of the aftermath of the revolution, women's role and women's movements have been suppressed by the state [15].

Egyptian women are also positioned behind the shadow of the Arab Spring. After the uprising in Egypt in 2011, and overthrown of Mubarak's regime, new elections were held and the MB won the majority of votes. Mursi, a member of the MB, became the new President. With Mursi's Islamic leaning constitution, women's status was altered. Women were publically suppressed and the government granted no protection to women.
Public opposition against Mursi's government appeared in November 2012 and by June 2013 there was a crackdown on the MB and a new constitution was drafted. The state was suffering from supporters of short-term government and military on one hand, and supporters of the MB on the other hand. However, Egyptian women seemed to be the main actors at disadvantage from the internal conflict.

Despite women's struggle and desire to draft a new accountable constitution, which ensures women's representation and protection, the struggles were soon followed by dissatisfaction in Egypt. After the Mubarak regime, the Constitutional Amendments Committee in Egypt was assigned to revise the constitution. The committee was all men, and after drafting the constitutions and forming the government, there were no women appointed as governors and only one woman out of 34 was appointed to the new cabinet. Although a Committee on Women was established within the new government, it had little power to bring any positive changes to post-revolutionary Egypt. With the creation of the committee and the little power it had, Egyptian women felt more frustrated and perceived that the committee was a window dressing intended to tell women they could have a committee, but the real political work must be done by men [11].

Amal Abdel Hadi, the founder of Egypt's New Woman Foundation, like many other activists in MENA, were seeking women's rights protection based on CEDAW principles. Hadi advocates that women need to participate in all areas of public life and they need to be active in the areas of politics, health, the economy, the environment, and working conditions in order to preserve their rights. Many of those activists who base their struggle on CEDAW principles have achieved a degree of success. For example, after much effort from Egyptian women, the government issued a decree on May 2011 allowing Egyptian women married to Palestinian men to pass their nationality to their children. The CEDAW for many Egyptian women was a key component in pushing the government to approve laws on woman to pass their nationality to their children. Notably, CEDAW is widely used by Egyptian women despite the obstacles towards women to pressure the government and initiate democracy in the state and bring about domestic reforms [25].

There were different indications to women's repression in the Arab world in general after the revolutions. The main factor seemed to be rise of Islamism in Egypt in particular. In fact, Islamic thoughts were rising even before the revolution in Egypt. There are two factors behind it; first many nongovernmental organizations have been seen to engage Islamic principles in their work, and second, many of the women's organizations were part of the Islamic groups [15].

One of the outcomes in the years following the Arab uprising was an alliance between Salafis and the MB, especially in Egypt. The fear of having Islamist militants in Egypt worried the majority during the early stages of government formation after the uprising, especially women. The call for implementation of Sharia indicated risky consequences for women in MENA. At the same time, the 
Islamist groups seemed to mobilize themselves more and more in Egypt among the lower classes [14, 17].

Many of those fundamentalist groups did not want women to be present in the public and political arena. They demanded that women's rights should not extend beyond the political upheavals. For instance, when 200 women showed up in Tahrir Square in Egypt to honor women's day, they were immediately attacked by the young Islamic fundamentalist militants and were forced to leave, being told they should go home and do housework instead [11].

Shirin Ebadi, 2003 Nobel Peace Prize Winner, stated in one article in Wall Street Journal warning Egyptian women about the role of Shari'a in repressing women. In the same article she argued that the revolution in Egypt and women's status aftermath is similar to women's status after the Iranian revolution. She stressed that the revolutionary men always tend to take advantage of women's contribution to the revolution and neglect their rights in the critical periods afterwards. She concluded in her article that Egyptian women will be able to thrive in all aspects of society only when democracy takes root and women become active in the civic life.

Furthermore, Egyptian women were discriminated economically additionally. Considering the status of women in Egypt which comes in the second class, it's very likely that the women's economic stand will get even worse as Brown suggests. Thus, the majority of Egyptian women believe that the only solution to improve women's condition is to replace the old systematic ways of government by secularist model of democratic regime, one that ensures gender equality.

\subsection{Arab Revolution in Libya}

February 2011 marked an end to Gaddafi's regime. Women were massively present in the demonstrations against the government. They were asking for equality and democracy and justice. Many of the Libyan women were not only supporting the families of the injured, but also holding arms against the regime and organizing demonstrations. However, their struggle for a new government that could grant women more rights seemed to be going unnoticed. The National Transitional Council (NTC) which led the revolutions in 2011; announced a new promised, pluralist and democratic state in 2012. However, NTC failed in legislating for equal rights in participation and representation for women in both the society and the state. For example, the Draft Constitution in August 2011 granted no conditions for prohibiting any sorts of discrimination against women. Moreover, there were no electoral laws in January 2011 to guarantee women's representation in the new parliament and among the 28 cabinet members, only two were women. One of the most challenging problems that faced the majority of Libyan women was the lack of opportunities for women to actively show their presence in public domain which remains to be present even today. This has hindered women economically. Besides due to sexual harassment and sexual assaults in public, makes it difficult for Libyan women to get employment opportunities in both public and private sectors [13].

Libyan women are still struggling to fit in into the new political arena. According to Rihab Elhaj, the co-founder and executive director of the New Libya Foundation, political aspirations remain overlooked, although women are working to find new careers and business enterprises in the new Libya. Libyan women are working hard to participate in public life, yet they are largely marginalized in public and through social norms. Although, women are not deprived from participation in the transitional government in Libya, their rights have been mainly neglected. As Elhaj stated that the Libyan women were largely unsure of women's empowerment, and the patriarchal values remain despite the hopes and struggles to obtain freedom and a more democratic Libya. She further explained that women's marginalization is due to returning to pre-revolutionary culture and social norms [26].

Soon after the collapse of the previous regime, the fair and free elections of the NTC provided 120 seats for independent candidates in Libya's General National Congress in 2011. However, from those 120 seats, 119 were men and only one woman was elected. Although women are not deprived of political participation in Libya, women's participation in politics were still very low with only 4 percent of women actively participating. There are different reasons for the lack of participation, including social and cultural obstacles towards women in addition to economic obstacles. On the other hand, biased interpretation of religion seems to play an important role in preventing women from participating in politics and addressing their rights [26].

Elizabeth Flock in Women in the Arab Spring: The Other Side of the Story argues that a lot has been written about women and their magnificent role in the Arab Spring, at the same time she describes the other side which is repressive and exposes the bitter truth. A newspaper in Libya, as she noted, has headlined stories about Arab women and their role in the Arab Spring. Among many of those women are the ones who have met countless hardships only because they are women. Many of them have been raped, or arrested. These are only few examples of endless brutal repression by men towards women during and after the Arab Spring in MENA [11].

\subsection{Morocco}

Like Jordan and Tunisia, the Arab uprising brought about a degree of reform in terms of women's liberation. However the case of Morocco seems to be a little different from other Arab states. In 2011, like the rest of the Arab states, activists and protestors launched demonstrations asking for an end of corruption and more freedom. After King Mohammed's review of the Constitution, women were granted more rights. For example, for the first time, five out 18 commission members were women and women's rights organizations like the Association Democratique des Femmes du Maroc (ADFM) played important roles in affirming women's rights in the state. Additionally, there were a number of changes in Morocco after the Constitution was amended. For instance, women alongside of men were granted equal status as citizens. The amendment also included ban on 
discrimination, and enhancing political, social, and economic equality for both men and women, providing equal access to elected position and ensuring governments' commitment in protecting women's rights.

In November 2011, the Islamist party of Justice and Development won the majority seats in election for the house of the representatives. The Islamist party's leader, Abdelilah Benkirane, formed a coalition that took power in 2012. Morocco's laws were derived from a hybrid of Islamic Sharia and French law. Many of the issues regarding women, like inheritance, divorce and child custody were all based on Sharia law and are governed by the family code to this day [2],[6]. Despite some positive changes for women in civil society after the uprisings, Moroccan women still have a long way into equality and justice in the political sphere.

\section{Conclusion}

While there was optimism for new democratic states in MENA after the uprising, Arab citizens were quite aware that their hopes and desires for social justice and democratic states might still be a dream to be realized someday. The Arab Uprising demonstrations were launched in February 20, 2011, and activists organized themselves. There was innumerable street protests calling for the overthrow of the regimes. The participants were mainly women and men from middle classes, and youth from urban areas. Although no Islamist groups participated in the initial uprisings, they soon emerged to try to take control of the demonstrations and there were fears that the Islamists would hijack the movements.

Women issues need to be addressed in the new constitutions in order to protect their rights, and to guarantee this, women need to be present at the tables of negotiation to address their issues. However, the danger with the peripheral threat of Sharia is that it puts women's rights largely under shadows, as it was the case in Egypt with MB and now in Syria and the Gulf States.

Noticeably, building new Arab states and drafting new constitutions and forming new governments are crucial for the Arab World. Moreover, empowering women's activities in public and in political participation is as important as building the states. Providing a quota system in parliaments for women is not the only solution to ensure women's rights; the new Arab governments need also to include capacity building, networking, and mentoring initiatives to educate not only women to protect their rights but also men.

The future of the Middle East still remains to a degree uncertain. Despite the fall of the authoritarian regime, there seems to be little or no evidence of democracy in the Middle East although the new elections results in Tunisia invites hope for the country, especially for women. In addition, the rise of Islamism especially in Egypt and Tunisia seemed to be the primary factor behind women's repression after the revolutions.

The hope of the Arab spring that millions of Arab women across the region had for better conditions haven't been met yet. To promote change, governments need to reconsider their constitution because changes are not possible in the society if the state does not enforce and support change. Holding accountable institutions are also important elements in determining legitimate social contract between the state and its citizens. Without the rule of law, democracy, education, and economic growth, women's status is not likely to improve.

\section{Acknowledgements}

I would like to thank my family for their support and encouragement always. I would also like to thank my university Chungnam National University for providing me with the opportunity in which I can use to explore my academic interests and my professor for his guidance and supervision.

\section{References}

[1] Al-Bizri, D. (2011), Women, Revolution, Politics and Power. Heinrich-Böll-Stiftung - Middle East Office, 9. Retrieved from: http://www.boell.org/downloads/Dalal_al-BizriWomen_Revolution_Politics_and_Power.pdf

[2] Arieff, A. (2013). Morocco: Current Issues. Congressional Reseach service, $20 . \quad$ Retrieved from: https://www.fas.org/sgp/crs/row/RS21579.pdf

[3] African Development Bank. (2012). Tunisia: economic and social changes beyond the Revolution, 52. Retrieved from: http://www.afdb.org/fileadmin/uploads/afdb/Documents/Publi cations/Tunisia\%20Economic\%20and\%20Social\%20Challeng es.pdf

[4] Borovsky, G. \& Yahia, A. B. (2012). Women's Political Participation in Tunisia After the Revolution.41. Retrieved from https://www.ndi.org/sites/default/files/womens-politicalparticipation-Tunisia-FG-2012-ENG.pdf

[5] World. (2013, May 29). Syrian refugees: Women in Jordan 'sexually exploited'. Retrieved from: http://www.bbc.co.uk/news/world-middle-east-22707377 [last accessed July 10, 2013].

[6] BBC World. (2013, December 16). Arab uprising: Country by country. Retrieved from: http://www.bbc.co.uk/news/world12482315 [last accessed December 25, 2013].

[7] Belhaj, R. M. \& Wiersinga, A. (2013). Wishes, Demands and Priorities of National and Regional Women's Organisations in the MENA Region. International Alliance of women, 48. Retrived from: https://www.coe.int/t/ngo/Source/IAW_arab_spring_report.pdf

[8] Brotman S., Katz, E., Karnes, J., West, W., Irvive, A., \& Daibes, D. (2008). Implementing CEDAW in North Africa and the Middle East: Roadblocks and victories. Middle East and North Africa (MENA) report, 35. Retrieved from: http://pages.uoregon.edu/aweiss/int1421_521/CEDAW_Report _MENAf.pdf

[9] Carothers, T. and Ottaway, M. (2005), Uncharted Journey: Promoting Democracy in the Middle East. Washington: Carnegie Endowment for International Peace. 
[10] Catalysts for change. (n.d.). Tunisian women: sustaining the fight for equal rights. 8. Retrieved from: http://www.solidaritycenter.org/Files/Tunisia.English\%20Final bug.pdf

[11] Dabash, H. (2012). The Arab spring: the end of post colonialism. London: Zed books.

[12] Hopman, P. T. \& Zartman, I. W. (n.d.). Tunisia: Understanding Conflict 2012. Johns Hopkins University School for Advanced International Studies, 241. Retrieved from: https://www.saisjhu.edu/sites/default/files/areas-ofstudy/files/Tunisia\%20Report\%20\%20April\%2017\%20Final.pdf

[13] Human Rights Watch. (2013). A revolution for all: women's rights in the new Libya, 44. Retrieved from: http://www.hrw.org/sites/default/files/reports/libya0513_broch ure_LOWRES.pdf

[14] Lynch, M. (2012). The Arab uprising: the unfinished revolutions of the Middle East. New York: Public Affairs.

[15] Mahmood, F. T. (2013). Women's Rights in Post Revolutionary Egypt: A Step Forward or Back? Ibn Khaldun Center for Development, 18. Retrieved from: http://www.ibnkhalduncenter.org/docs/Women's_Rights.pdf

[16] O'Byrne, D. J. (2003), Human Rights: An Introduction. London. Kuala Lumpur: Pearson Education Limited.

[17] Ramadan, T. (2012). The Arab awakening: Islam \& the new Middle East. New York: Penguin Group

[18] Saloom, R. (2007). "Women After": An Interdisciplinary Examination of Gender in Palestinian Nationalism and the Iranian Revolution. Michigan State Journal of Gender and Law. Retrieved from: http://heinonline.org/HOL/LandingPage?collection=journals\& handle $=$ hein.journals $/ \mathrm{msjgl} 2007 \& \mathrm{div}=5 \& \mathrm{id}=\&$ page $=$
[19] Salame, G. (1994). Democracy without Democrats? the renewal of politics in the Muslim world. London: I.B. Tauris \& Co Ltd.

[20] Skocpol, T. (1979). States and Social Revolutions: A Comparative Analysis of France, Russia, and China. Cambridge. United Kingdom: Cambridge University Press.

[21] Strum, P. (2013) educating for democracy. Washington, DC: Woodrow Wilson International Center for Scholars, Division of US Studies, 62. Retrieved from: http://www.wilsoncenter.org/sites/default/files/educatingforde mocracy.pdf

[22] Şahin, P. G. (n.d.). Women's liberties and gender equality in tunisia: the asthma of the Arab spring? Turkish policy quarterly, $8 . \quad$ Retrieved from: http://www.turkishpolicy.com/dosyalar/files/vol_11no_4\%20sahin.pdf

[23] Sharabi, H. (1988). Neopatriarchy: the theory of distorted change in Arab society. New York: Oxford university press, Inc.

[24] Soage, A. (2009). Introduction to Political Islam. 11. Retrieved from: https://www.researchgate.net/publication/264412727_Introduc tion_to_Political_Islam

[25] Women's Learning Partnership. (n.d.). Women's Rights, and the Arab Spring: Fact Sheet on Egypt, Tunisia, Morocco and Jordan, 6.6 Retrieved from: http://www.foreign.senate.gov/imo/media/doc/Mahnaz_Afkha mi_Testimony_Appendix.pdf

[26] Wilson Center. (2012). after the Arab Awakening. 38. Retrieved from: http://www.wilsoncenter.org/sites/default/files/Arab\%20Awak ening\%20Marginalizing\%20Women_0.pdf 